\title{
Kinetics of pancreatic juice secretion in relation to duodenal migrating myoelectric complex in preruminant and ruminant calves fed twice daily
}

\author{
BY ROMUALD ZABIELSKI, PAWEK KIELA, VIOLETTA LEŚNIEWSKA, \\ RYSZARD KRZEMIŃSKI, MARIOLETTA MIKOLAJCZYK AND WIESEAW BAREJ \\ Department of Animal Physiology, Faculty of Veterinary Medicine, Warsaw Agricultural University, \\ ul. Nowoursynowska 166, 02-787 Warsaw, Poland
}

(Received 19 January 1996 - Revised 4 February 1997 - Accepted 12 February 1997)

\begin{abstract}
Daily secretion of pancreatic juice, including postprandial responses to food, was investigated in two groups of calves: preruminant (fed with liquid food) and ruminant (fed with solid food). Male Friesian calves ( 1 week old and 6 weeks old) were surgically fitted with a pancreatic duct catheter, duodenal cannula and two duodenal electrodes. Continuous $24 \mathrm{~h}$ collections of pancreatic juice and myoelectrical recordings were performed with minimal restraint and disturbance of animals. In both groups of calves clear periodic fluctuations in pancreatic juice secretion (volume, protein output and trypsin activity) coinciding with duodenal migrating myoelectric complexes (MMC) were recorded. Secretion of juice per cycle and per day was greater in ruminant calves, but the frequency and amplitude of cycles were lower in this group. There were no differences between day and night-time preprandial pancreatic cycles and duodenal MMC in preruminant calves, whilst in ruminant calves, evening MMC were longer than morning MMC. The pancreatic cephalic phase (increase of volume flow, protein output and trypsin activity during and just after food intake) was significant only in preruminant calves following morning feeding. Postprandial pancreatic cycles did not differ from preprandial cycles, except the pancreatic cycle (juice volume and trypsin activity) in which food was offered in preruminant calves. No gastric or intestinal phase was observed in either group of calves. In conclusion, biological cycles of the gastrointestinal tract are present in both preruminant and ruminant calves, and these cycles evolve along with the change from liquid to solid food.
\end{abstract}

Pancreas: Duodenum: Myoelectrical activity: Calf

In young growing ruminants, the most dramatic transformation of the gastrointestinal tract appears at about the time of weaning. It concerns both anatomical and functional changes which are largely diet-dependent (Ruckebusch \& Bueno, 1973; Ruckebusch et al. 1983). At that time the exocrine pancreas, which produces the bulk of enzymes for food digestion, develops very intensively: it increases its weight (Ternouth \& Buttle, 1973) and modifies the enzymic profile as observed in pancreatic tissue homogenates (Guilloteau et al. 1983; Le Huërou et al. 1990). The volume of pancreatic juice in calves gradually increases with age (McCormick \& Stewart, 1966). The secretion of particular enzymes (Ternouth et al. 1976; Pierzynowski et al. 1990) as well as the neurohormonal mechanisms responsible for the regulation of this secretion (Guilloteau et al. 1992; Toullec et al. 1992; Le Meuth et al. 1993; Zabielski, 1994) are also transformed.

According to McCormick \& Stewart (1966) and Ternouth \& Buttle (1973), the exocrine pancreas secretes the juice in a characteristic manner in preruminant calves. During feeding, and for several minutes after it, the secretion is increased above the 
preprandial level, after that the secretion decreases for about $2-3 \mathrm{~h}$ and then shows a second postprandial peak lasting for about $4 \mathrm{~h}$. It was assumed that the first peak was a result of cephalic stimulation driven by the vagal cholinergic pathway (Pierzynowski et al. 1992), and the second one might be the so-called intestinal phase coinciding with elevated flow of digesta through the small intestine (McCormick \& Stewart, 1966). Interestingly, no gastric phase was observed in calves (McCormick \& Stewart, 1966) although studies with electromagnetic flow-meters implanted in the duodenum showed a significant increase in abomasal emptying in the first hour after milk ingestion (Girard \& Sissons, 1992). A similar pattern of postprandial secretion was also observed in preruminant goats by Naranjo et al. (1986). In contrast to results obtained in preruminant calves and goats, feeding did not cause so dramatic a stimulation of pancreatic secretion, if any, in ruminant calves and in adult cattle and sheep (Pierzynowski et al. 1990, 1991; Kato et al. 1991).

Recent studies have revealed that pancreatic secretion in preruminant calves is periodic (Zabielski et al. 1993; Zabielski, 1994). This pattern is to some extent similar to the periodic pancreatic secretion (PPS) observed in dogs (Boldyreff, 1911; Magee \& Naruse, 1983; Konturek et al. 1986), pigs (Abello et al. 1988; Kiela et al. 1996), rats (Onaga et al. 1993) and human subjects (Vantrappen et al. 1979). It is manifested by cyclically recurring fluctuations in the secretion of pancreatic juice concomitant with the migrating myoelectric complex (MMC) of the duodenum. However, these pancreatic and duodenal fluctuations in preruminant calves were much less affected by food ingestion than fluctuations observed in dogs and rats (Konturek et al. 1986; Onaga et al. 1993; Zabielski et al. 1993) but were similar to fluctuations recorded in pigs fed twice daily (Kiela, 1996). Podgurniak \& Pierzynowski (1993) were the first to report that some fluctuations resembling PPS are present in ruminant calves. However, they did not perform simultaneous recording of motor or electrical activity of the gastrointestinal tract. The daily profile of pancreatic secretion (involving effect of morning and evening feeding) in terms of PPS fluctuations coinciding with duodenal MMC has not been investigated in young calves. In most of the studies performed so far, collections of pancreatic secretions have started in the morning and lasted for a maximum of $8 \mathrm{~h}$ thus involving only the response to morning feeding.

The aim of the present study was to monitor continuously for $24 \mathrm{~h}$ the secretion of pancreatic juice and the electrical activity of the duodenum in two age-groups of calves: preruminant (fed with liquid food) and early ruminant (fed with solid food). Studies in human subjects and in rats have suggested that pancreatic secretion is not uniform throughout the day (Gullo et al. 1987; Maouyo et al. 1993). In the present study day-time (preprandial and postprandial) pancreatic secretion and duodenal MMC were compared with the respective night-time secretion in order to examine eventual daily differences. Collections of pancreatic juice and myoelectrical recordings were performed with minimal restraint and disturbance of animals.

\section{EXPERIMENTAL METHODS}

\section{Animal preparation}

In four 1-week-old and four 6-week-old male Friesian calves (46 (SEM 3) kg and 63 (SEM 3 ) $\mathrm{kg}$ body weight (BW) respectively) the pancreatic accessory duct and duodenum were catheterized and two silver bipolar electrodes were implanted on the proximal duodenum. Electrode 1 was implanted $40 \mathrm{~mm}$ posterior to the duodenal bulb, and electrode 2 was sutured $40 \mathrm{~mm}$ anterior to the pancreatic accessory duct orifice (Zabielski et al. 1993). For surgery, the animals were premedicated with atropine $(0.01 \mathrm{mg} / \mathrm{kg} ;$ Atropinum Sulfuricum, Polfa, Poland) and $2 \%$ xylazine ( $0.15 \mathrm{ml} / \mathrm{kg}$; Rompun, Bayer, Germany), 
and anesthetized with halothane (Narkotan, Spofa, Czechoslovakia). Procaine penicillin (600 $000 \mathrm{IU}$, Polfa, Poland) was administered intramuscularly for $5 \mathrm{~d}$ after the surgery. The calves quickly recovered from the surgery and normal duodenal electrical activity was registered from the second and third post-operative days.

\section{Animal management}

Calves were kept in pens $(1.20 \times 1.20 \mathrm{~m})$ allowing free movement but assuring sufficient restraint for the recordings. The calves received their food twice daily, at 08.00 and 20.00 hours. The composition of the feeds is shown in Table 1. Liquid food (i.e. milk replacer) was given from the bucket and it was consumed within 2-5 min. Powdered milk replacer (Mlekomix, Polfa, Poland), was mixed with water $(1: 9, \mathrm{w} / \mathrm{v})$ immediately before feeding. Solid food (i.e. concentrate and meadow hay) was offered to the calves in the feeding trough, and it was consumed within 10-15 min. Water was allowed ad libitum. The daily intake of DM is given in Table 2; the daily weight gain was 0.22 (SEM 0.06) $\mathrm{kg} / \mathrm{d}$ for preruminant and 0.32 (SEM 0.08 ) $\mathrm{kg} / \mathrm{d}$ for ruminant calves. All the calves examined had a good appetite and appeared clinically healthy throughout the entire study.

\section{Pancreatic juice collection and duodenal recordings}

Continuous $24 \mathrm{~h}$ collections of pancreatic juice (starting from 06.00 hours) and recordings of the duodenal electrical activity were performed on each calf on day 7 after the surgery. In two preruminant calves and three ruminant calves, the collections were repeated on day 14 after the surgery. Thus, in preruminant calves the collections were done when they were 2 and 3 weeks old, and in ruminant calves when they were 7 and 8 weeks old. However, for further analysis of the data the mean value was calculated for each time point for these 'repeated' calves using the data from the first collection and from the collection repeated 1 week later, thus the final $n$ value was 4 , as was the number of animals (the differences between the first collection and the repeated one were small compared with the animal-toanimal variation and therefore were neglected). The indwelling electrodes were connected to an amplifier (BioAmp, ADInstruments, Australia) with high- and low-frequency cut-off filters of 50 and $3 \mathrm{~Hz}$ respectively. Signals were recorded with an Apple computer-based data recording system (MacLab, ADInstruments). Duodenal tracings, raw data and on-line spike frequency analysis (Chart v3.3, ADInstruments), were inspected for the phases of the MMC on the computer monitor. Pancreatic juice was collected continuously into plastic

Table 1. Chemical composition of feed for calves $(\mathrm{g} / \mathrm{kg} \mathrm{DM})$

(Mean values for eight weekly composites)

\begin{tabular}{lccr}
\hline \hline Item & Milk replacer $\dagger$ & $\begin{array}{c}\text { Commercial concentrate } \\
\text { complete starter ration }\end{array}$ & Hay \\
\hline Crude protein & 232 & 189 & 143 \\
Ash & 74 & 43 & 77 \\
Crude fibre & - & 49 & 316 \\
Ether extract & 181 & 22 & 23 \\
\hline
\end{tabular}

* DM contents of milk replacer, commercial concentrate and hay were 918,933 and $925 \mathrm{~g} / \mathrm{kg}$ fresh weight respectively.

$\dagger$ Ingredients of milk replacer were $(\mathrm{g} / \mathrm{kg})$ : skimmed milk powder 650 , whey powder 140 , fat 170, starch $20, \mathrm{D}, \mathrm{L}$ methionine $1 \cdot 8$, vitamins and minerals $18 \cdot 2$.

$\ddagger$ Ingredients of commercial concentrate $(\mathrm{g} / \mathrm{kg})$ : bran 130 , ground wheat 258 , ground oat 240 , ground barley 140 , rapeseed meal 160 , soyabean meal 72 . 
Table 2. Daily intake of $D M(g / d)$ from milk replacer, commercial concentrate and hay for calves

\begin{tabular}{lccc}
\hline \hline Age (d) & Milk replacer & $\begin{array}{c}\text { Commercial concentrate } \\
\text { complete starter ration }\end{array}$ & Hay \\
\hline $14-28$ & $459 \cdot 0$ & - & - \\
$29-42$ & 230.0 & $340 \cdot 0$ & $91 \cdot 0$ \\
$43+$ & - & $950 \cdot 0$ & $240 \cdot 0$ \\
\hline
\end{tabular}

vials by gravity drainage $(100 \mathrm{~mm})$, and the tubes were changed manually according to the following protocol. Starting from 06.00 hours pancreatic juice was collected at $5 \mathrm{~min}$ intervals until 10.00 hours. In the meantime the calves received their morning food. The moment of feeding was determined by the MMC recording; feeding started during the late no spiking activity (NSA) phase that appeared at 08.00 hours $\pm 15 \mathrm{~min}$. The same procedure of sampling was repeated starting from 18.00 until 22.00 hours with evening feeding performed at 20.00 hours $\pm 15 \mathrm{~min}$. Between 10.00 and 18.00 hours and between 22.00 and 06.00 hours the juice was sampled in phase with duodenal MMC in order to reduce the number of samples. The electromyographical recording was analysed visually on-line for phases of the MMC, and in each MMC cycle the tube was changed only twice: the sample collected during the NSA phase in the duodenum (NSA sample) reflected the trough secretion in the PPS cycle (Zabielski et al. 1993). The sample collected during the irregular (ISA) + regular spiking activity (RSA) phases in duodenal MMC (ISA + RSA sample) reflected the peak secretion in the PPS cycle. The volume of each sample of pancreatic juice was measured and $0.2 \mathrm{ml}$ was taken for analysis. The remainder was infused into the duodenum by means of a peristaltic pump (PP1B-05, Zalimp, Poland) in the next respective phase of the duodenal MMC. Between 06.00 and 10.00 hours and between 18.00 and 20.00 hours, when juice was sampled according to a 5 min protocol, the remainder of pancreatic juice was infused in the next 5 min period.

\section{Analysis, calculations and statistical tests}

Each experiment lasting $24 \mathrm{~h}$ (from 06.00 hours one day to 06.00 hours the next day) was regarded as a closed circle. Data recorded in the early morning before the end of the experiment were thus used as a control for the morning feeding performed at the beginning of this experiment. The frequency of spikes ( $\mathrm{Hz}$, results not shown) and the duration of MMC cycles in the duodenum (min) are expressed as mean values, standard error of the mean (SEM) and standard error of the difference between means (SED) when appropriate. The accuracy of visual on-line analysis of the MMC (and changes of the tubes for juice collection) was high in comparison with the tracing analysis performed after recording: the beginning of an NSA sample was recognized within 10-15 s after termination of the RSA phase and the beginning of an ISA + RSA sample was recognized within 20-30s after termination of the NSA phase.

For comparisons of MMC variables between the two age-feeding groups, Student's unpaired $t$ test was applied. Student's paired $t$ test was used for comparisons within the groups.

Samples of pancreatic juice were analysed for total protein (Lowry et al. 1951) and trypsin activity (Erlanger et al. 1961) with further modifications for ninety-six vial microplates (Zabielski et al. 1992a). The trypsin activity expressed in units (U), was defined as the amount of enzyme hydrolysing $1 \mu \mathrm{mol}$ substrate BAPNA $(N \alpha$-benzoyl-DLarginine-p-nitroanilide; Sigma, St Louis, MO, USA) per min. 
Data from 5 min samples of pancreatic juice that were collected $2 \mathrm{~h}$ before and $2 \mathrm{~h}$ after feeding were recalculated in three ways. (1) The data from the $5 \mathrm{~min}$ sampling periods were summed into two preprandial $1 \mathrm{~h}$ periods and two $1 \mathrm{~h}$ postprandial periods for calculations that were done regardless of the periodic secretion of the pancreas. (2) The data from three consecutive 5 min sampling periods obtained following the start of feeding were summed into a 15 min period. These summed data were used for examination of direct effects of feeding on pancreatic secretion (cephalic phase of pancreatic secretion). (3) The data from the $5 \mathrm{~min}$ sampling periods obtained $2 \mathrm{~h}$ before and $2 \mathrm{~h}$ after feeding were summed to match phases of respective duodenal $\mathrm{MMC}$ in order to reconstruct the periodic fluctuations around the feeding time. These 'reconstructed' data together with the data from 10.00 18.00 hours and 22.00-06.00 hours were used for examination of a daily profile of pancreatic fluctuations in the calves examined. After the computing of the juice flow $(\mathrm{ml} / \mathrm{kg}$ per $\mathrm{h}$ ), protein output $(\mathrm{mg} / \mathrm{kg}$ per $\mathrm{h})$ and trypsin output $(\mathrm{U} / \mathrm{kg}$ per $\mathrm{h})$, the data were averaged and expressed as mean values and SEM. Statistical evaluation was done using the unpaired $t$ test for comparison between the groups, and the paired $t$ test and repeated measures ANOVA followed by the Tukey-Kramer multiple comparison test for comparison within the group (InStat for Macintosh v. 2.03, GraphPad Software, USA). In all statistical analyses $P<0.05$ was taken as the level of significance.

\section{RESULTS}

Duration of duodenal migrating myoelectric complexes and periodic pancreatic secretion cycles

Normal MMC coinciding with PPS cycles were recorded in the duodenum from the second or third postoperative day in all experimental calves. On average, totals of 42.3 (SEM 2.4) and 32.7 (SEM 2.3) MMC cycles per $24 \mathrm{~h}$ passed through the duodenum in preruminant and ruminant calves respectively (unpaired $t$ test, $P<0.05$ ). The mean duration of one MMC cycle in preruminant calves was 34.2 (SEM 3.4) min, and it was significantly shorter than in ruminant calves (44.3 SEM $2.5 \mathrm{~min}$ ) (unpaired $t$ test, $P<0.05$ ).

Three phases of duodenal MMC (NSA, ISA and RSA) could be easily distinguished in most of the myoelectrical tracings. The duration of MMC phases (based on four MMC cycles before administering food) is shown in Table 3. No significant difference was observed between morning and evening MMC cycles in preruminant calves. In ruminant calves the evening MMC cycles were longer than the morning ones due to longer duration of ISA (paired $t$ test, $P<0.05$ ).

Feeding modified significantly the duodenal MMC cycles in which food was given but did not influence the synchronization between duodenal motility and PPS in any of the groups studied. In preruminant calves, the MMC cycle during both morning and evening feeding was significantly prolonged as compared with the last preprandial cycle (Table 4). In ruminant calves, however, only morning feeding prolonged significantly the prandial MMC cycle.

In preruminant calves, the mean duration of postprandial MMC (Table 5) was longer than that of preprandial (Table 3) cycles in the evening (in the morning, there was an increasing tendency, paired $t$ test $P=0.08$ ), whereas in ruminant calves, it was longer in the morning. This could be attributed to the duration of ISA phases which tended to increase in preruminant (paired $t$ test, $P=0.15$ ) and the duration of the morning ISA which was increased in ruminant calves (paired $t$ test, $P<0.05$ ) (Tables 3 and 5 ) as well as the duration of NSA phase which tended to decrease in both preruminant (paired $t$ test, $P=0.21$ ) and ruminant calves (paired $t$ test, $P=0.055$ ). In both groups of calves, the 
Table 3. Duration of phases of duodenal migrating myoelectric complex (MMC) (min) during the interdigestive period (four MMC last cycles before feeding) in preruminant and ruminant calves

(Mean values with their standard errors for four calves)

\begin{tabular}{|c|c|c|c|c|c|}
\hline \multirow[b]{2}{*}{ Phase } & \multicolumn{2}{|c|}{ Morning } & \multicolumn{2}{|c|}{ Evening } & \multirow[b]{2}{*}{ SED } \\
\hline & Mean & SEM & Mean & SEM & \\
\hline \multicolumn{6}{|c|}{ Preruminant calves } \\
\hline NSA & $10 \cdot 6$ & 1.4 & 9.8 & 1.1 & $1 \cdot 1$ \\
\hline ISA & 19.2 & $2 \cdot 3$ & 19.8 & $3 \cdot 1$ & 4.6 \\
\hline RSA & $2 \cdot 2$ & 0.2 & 2.0 & 0.2 & 0.1 \\
\hline Total MMC & 32.4 & 0.8 & 31.9 & $4 \cdot 3$ & $4 \cdot 0$ \\
\hline \multicolumn{6}{|c|}{ Ruminant calves } \\
\hline NSA & $6 \cdot 9$ & 0.9 & 7.9 & 0.9 & 0.3 \\
\hline ISA & $28 \cdot 0$ & $3 \cdot 2$ & $34 \cdot 6^{*}$ & 3.5 & $1 \cdot 5$ \\
\hline RSA & 1.7 & 0.2 & 1.7 & 0.2 & 0.1 \\
\hline Total MMC & $36 \cdot 9$ & $2 \cdot 2$ & $44 \cdot 4 * \dagger$ & 1.2 & $1 \cdot 1$ \\
\hline
\end{tabular}

NSA, no spiking activity; ISA, irregular spiking activity; RSA, regular spiking activity.

* Mean values were significantly different from those for the morning, $P<0.05$ (paired $t$ test).

$\dagger$ Mean value was significantly different from that for preruminant calves, $P<0.05$ (unpaired $t$ test).

duration of MMC phases recorded following morning feeding were not statistically different from that recorded in the evening (Table 5). As in preprandial cycles and in the cycle in which food was offered, there was a synchronization of duodenal and pancreatic cycles.

\section{Pancreatic secretion in calves}

The daily outflow of pancreatic juice was 7.9 (SEM 1.0) $\mathrm{ml} / \mathrm{kg} \mathrm{BW}$ in preruminant calves, and 14.2 (SEM 2.8 ) $\mathrm{ml} / \mathrm{kg} \mathrm{BW}$ in ruminant calves (unpaired $t$ test, $P<0.05$ ). Similarly, the daily protein output in preruminant calves was as low as 0.04 (SEM 0.009 ) $\mathrm{g} / \mathrm{kg} \mathrm{BW}$, while in ruminant calves it was 0.12 (SEM 0.03 ) $\mathrm{g} / \mathrm{kg} \mathrm{BW}$ (unpaired $t$ test, $P<0.05$ ). Despite these marked quantitative differences in the daily juice outflow and protein output between

Table 4. Effect of feeding on the duration of migrating myoelectric complex and periodic pancreatic secretion cycles ( $\mathrm{min}$ ) in preruminant and ruminant calves

(Mean values with their standard errors for four calves; values are for the last preprandial cycle and the cycle in which food was offered)

\begin{tabular}{|c|c|c|c|c|}
\hline \multirow[b]{2}{*}{ Cycles } & \multicolumn{2}{|c|}{ Morning } & \multicolumn{2}{|c|}{ Evening } \\
\hline & Mean & SEM & Mean & SEM \\
\hline \multicolumn{5}{|l|}{ Preruminant calves } \\
\hline Preprandial & $33 \cdot 3$ & $1 \cdot 3$ & 33.7 & $3 \cdot 3$ \\
\hline Food-stimulated & $62 \cdot 6^{*}$ & $10 \cdot 2$ & $46 \cdot 0^{*}$ & $10 \cdot 5$ \\
\hline SED & 9.0 & & $8 \cdot 1$ & \\
\hline \multicolumn{5}{|l|}{ Ruminant calves } \\
\hline Preprandial & 41.9 & $2 \cdot 5$ & $45 \cdot 5$ & $2 \cdot 3$ \\
\hline Food-stimulated & $53 \cdot 9 *$ & $6 \cdot 1$ & $49 \cdot 0$ & $13 \cdot 5$ \\
\hline SED & $5 \cdot 9$ & & 9.5 & \\
\hline
\end{tabular}

\footnotetext{
* Mean values were significantly different from those for the corresponding preprandial cycles, $P<0.05$ (paired $t$ test).
} 
Table 5. Duration of phases of duodenal migrating myoelectric complex (MMC) (min) after feeding (six postprandial MMC cycles starting from the second $M M C$ following feeding) in preruminant and ruminant calves

(Mean values with their standard errors for four calves)

\begin{tabular}{|c|c|c|c|c|c|}
\hline \multirow[b]{2}{*}{ Phase } & \multicolumn{2}{|c|}{ Morning } & \multicolumn{2}{|c|}{ Evening } & \multirow[b]{2}{*}{ SED } \\
\hline & Mean & SEM & Mean & SEM & \\
\hline \multicolumn{6}{|c|}{ Preruminant calves } \\
\hline NSA & $8 \cdot 8$ & 1.9 & $8 \cdot 4$ & 1.4 & 1.7 \\
\hline ISA & 23.9 & $2 \cdot 5$ & $26 \cdot 5$ & $3 \cdot 1$ & 2.9 \\
\hline RSA & 1.6 & 0.3 & 1.8 & 0.2 & 0.3 \\
\hline Total MMC & 34.7 & $3 \cdot 1$ & 37.0 & 0.7 & 3.4 \\
\hline \multicolumn{6}{|l|}{ Ruminant calves } \\
\hline NSA & $6 \cdot 2$ & 0.8 & $5 \cdot 6$ & 0.6 & 0.6 \\
\hline ISA & 34.5 & 3.7 & 37.7 & 4.0 & 0.5 \\
\hline RSA & 1.6 & 0.1 & 1.7 & 0.2 & 0.1 \\
\hline Total MMC & $42 \cdot 5$ & 1.7 & $44.8 *$ & $2 \cdot 1$ & 0.5 \\
\hline
\end{tabular}

NSA, no spiking activity; ISA, irregular spiking activity; RSA, regular spiking activity.

* Mean value was significantly different from that for preruminant calves, $P<0.05$ (unpaired $t$ test).

preruminant and ruminant calves, the interdigestive pancreatic secretion fluctuated periodically in both groups (Figs. 1, 2 and 3), and the PPS cycles were precisely synchronized in phase with the duodenal MMC. The lowest juice secretion, protein output and trypsin activity were observed in samples collected during duodenal NSA and significantly higher secretion was observed in ISA + RSA samples in both groups examined (paired $t$ test, $P<0.05$ ). The difference between the secretion in NSA and ISA + RSA phases in PPS cycles (juice flow, protein output and trypsin output) was greater in preruminant calves than in ruminant calves (unpaired $t$ test, $P<0.05$ ). There was no significant difference between morning and evening interdigestive periodic secretion in the two groups of calves.

Pancreatic secretory response to feeding in preruminant calves (the secretion for $2 \mathrm{~h}$ following morning $+2 \mathrm{~h}$ following evening feeding) was $21 \%$ of daily pancreatic juice secretion, and $29.4 \%$ of daily protein output. Morning feeding caused a temporary dramatic increase in all measured variables (juice flow, protein output, trypsin output) lasting $15 \mathrm{~min}$ in preruminant calves (Table 6). The entire response to food was completed within $1 \mathrm{~h}$; in the second hour following feeding pancreatic juice was secreted in the preprandial range. Morning feeding stimulated the exocrine pancreas more strongly than evening feeding (Table 6). The contribution of $2 \mathrm{~h}$ postprandial secretion to total daily secretion amounted to $13 \%$ and $8 \%$ for juice outflow (paired $t$ test, $P<0.05$ ), and to $19 \%$ and $10.4 \%$ for protein output (paired $t$ test, $P<0.05$ ) after morning and evening feeding respectively.

In contrast to preruminant calves, there was no significant increase in pancreatic juice secretion in the first $2 \mathrm{~h}$ following feeding (except for trypsin during evening feeding) in ruminant calves. There was an increase in protein output in the second hour following morning feeding (Table 6). The contributions of $2 \mathrm{~h}$ postprandial to total daily fluid and protein outputs were, respectively, $7.7 \%$ and $7.7 \%$ for morning feeding and $6.4 \%$ and $5.7 \%$ for evening feeding.

Figs. 1, 2 and 3 illustrate pancreatic secretion within $15 \mathrm{~min}$ following food ingestion: the greatest response was observed in juice flow and trypsin output in preruminant calves for morning feeding, whereas evening feeding in preruminant calves and both feedings in 


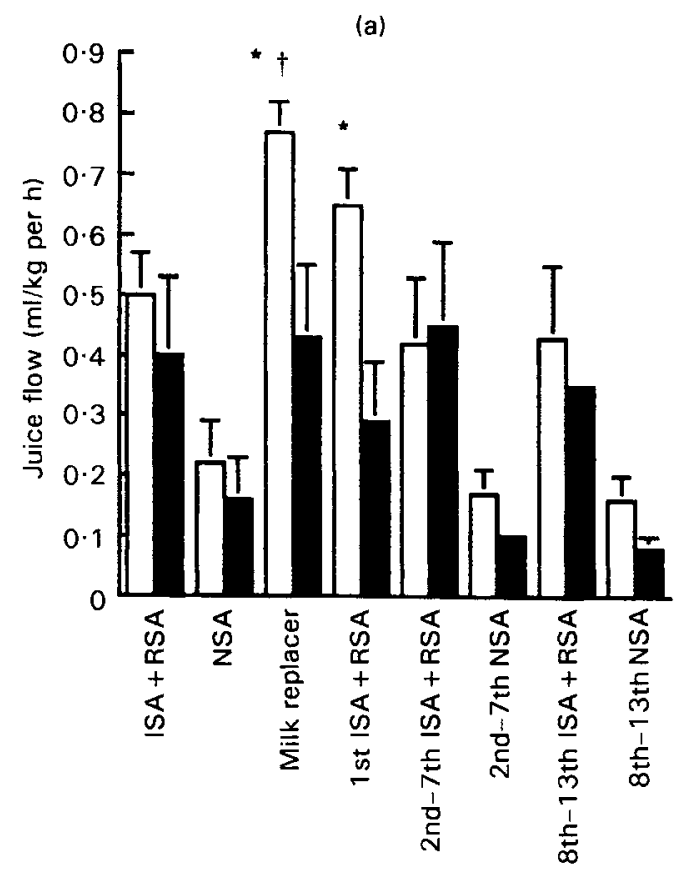

(b)

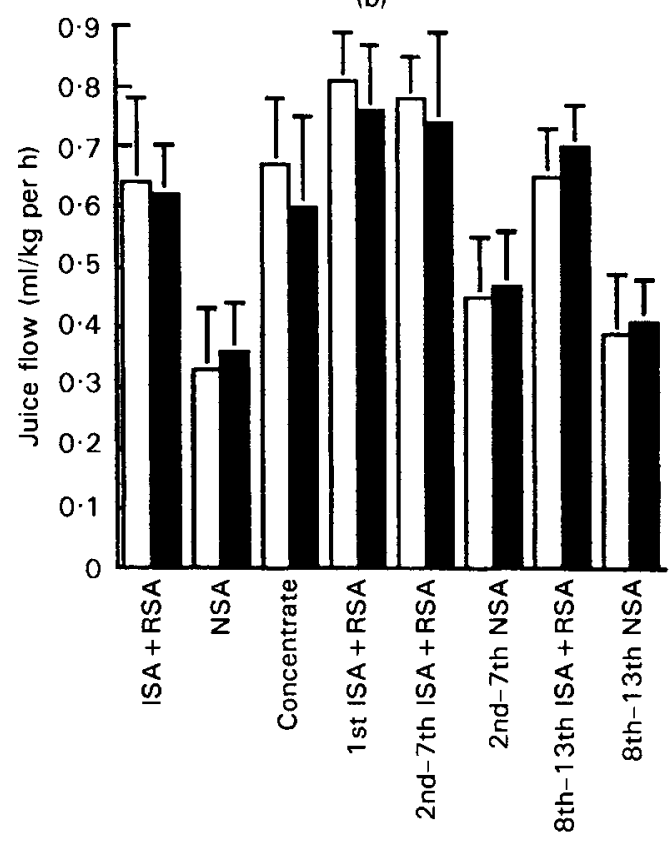

Fig. 1. Morning ( $\square$ ) and evening ( $\square$ ) flows of pancreatic juice in (a) preruminant and (b) ruminant calves. Periodic pancreatic secretion (PPS) was monitored according to phases of duodenal migrating myoelectric complex (irregular spike activity (ISA) and regular spike activity (RSA) bars reflect the secretion collected during recording of ISA and RSA phases in the duodenum, and no spike activity (NSA) bars reflect the secretion collected during recording of NSA phase in the duodenum). The first two pairs of bars reflect the mean preprandial secretion of four PPS cycles before feeding. The next pair of bars indicates the direct response to milk replacer or concentrate and hay (15 min collection during and just after offering the food). The 1st ISA + RSA pair of bars reflects the mean secretion in the ISA + RSA phase in which food was offered. The succeeding pairs of bars indicate mean secretion in ISA + RSA and NSA collections in twelve consecutive postprandial cycles. Values are means for four calves, with their standard errors indicated by vertical bars. * Mean values were significantly different between bars in a pair, $P<0.05$ (paired $t$ test). $\dagger$ Mean value was significantly different from the preprandial secretion during ISA + RSA, $P<0 \cdot 05$ (paired $t$ test). 


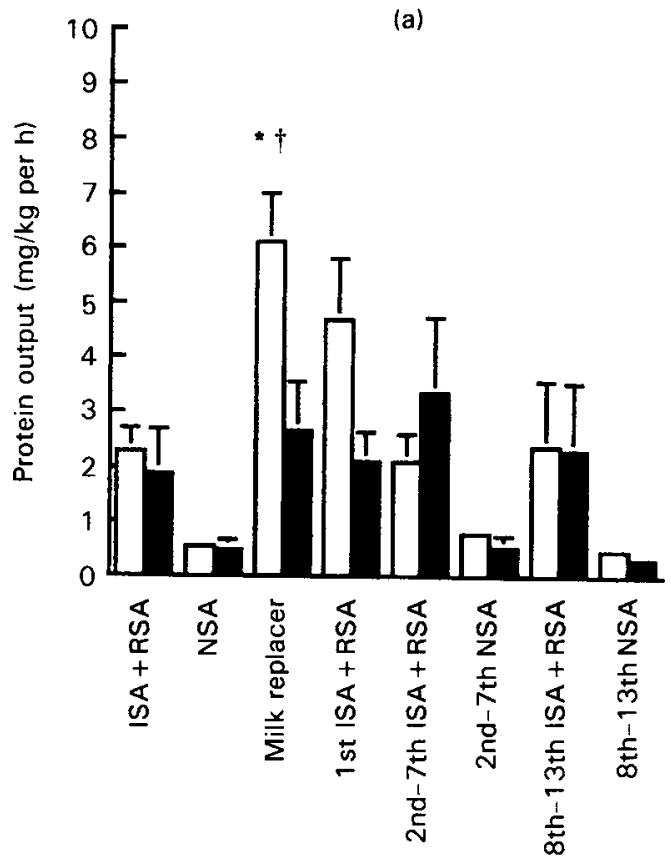

(b)

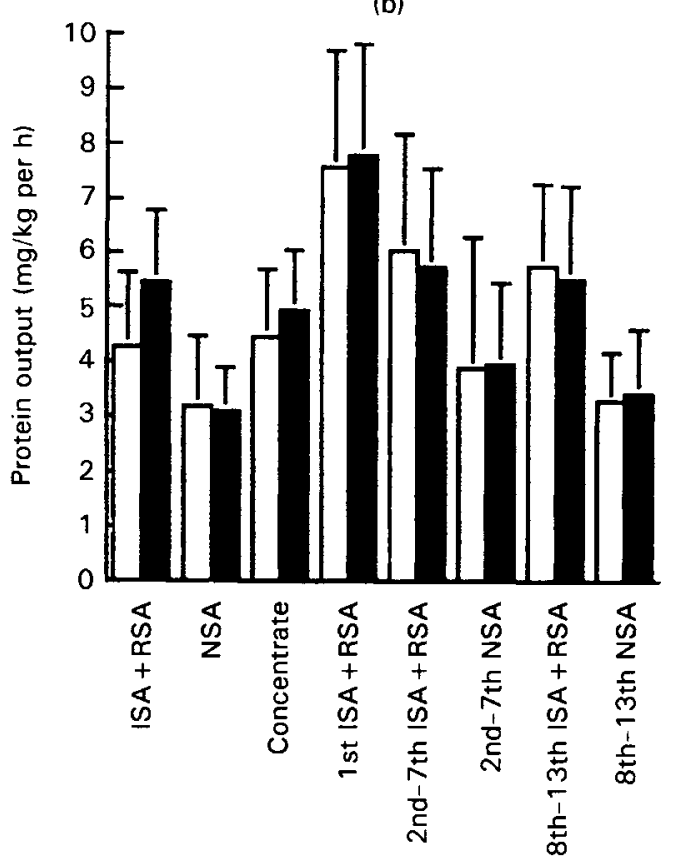

Fig. 2. Moming ( $\square$ ) and evening ( $\square$ ) outputs of pancreatic protein in (a) preruminant and (b) ruminant calves. Periodic pancreatic secretion (PPS) was monitored according to phases of duodenal migrating myoelectric complex; for details, see legend to Fig. 1. Values are means for four calves, with their standard errors represented by vertical bars. * Mean values were significantly different between bars in a pair, $P<0.05$ (paired $t$ test). $\dagger$ Mean value was significantly different from the preprandial secretion during ISA + RSA, $P<0.05$ (paired $t$ test). 

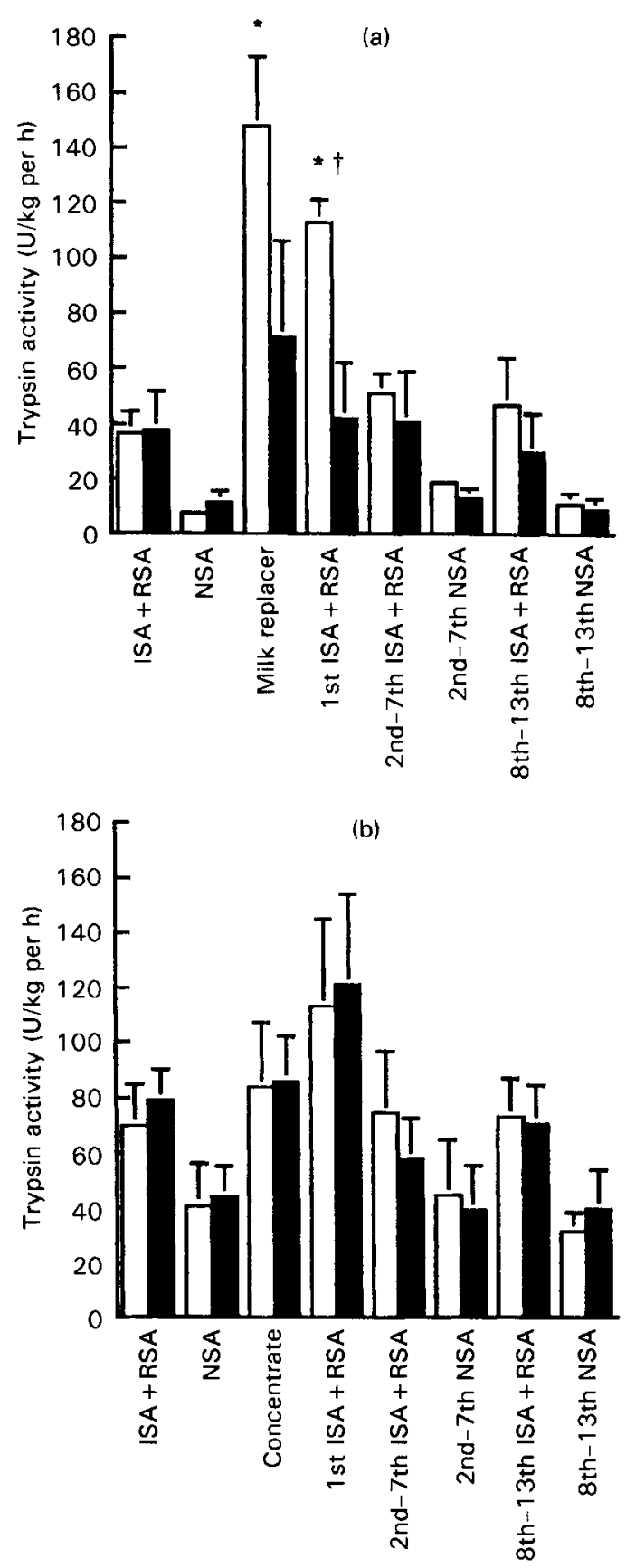

Fig. 3. Morning ( $\square$ ) and evening ( $\square$ ) outputs of pancreatic trypsin in (a) preruminant and (b) ruminant calves. Periodic pancreatic secretion (PPS) was monitored according to phases of duodenal migrating myoelectric complex; for details, see legend to Fig. 1. Values are means for four calves, with their standard errors represented by vertical bars. ${ }^{*}$ Mean values were significantly different between bars in a pair, $P<0.05$ (paired $t$ test). $\dagger$ Mean value was significantly different from the preprandial secretion during ISA + RSA, $P<0.05$ (paired $t$ test). 


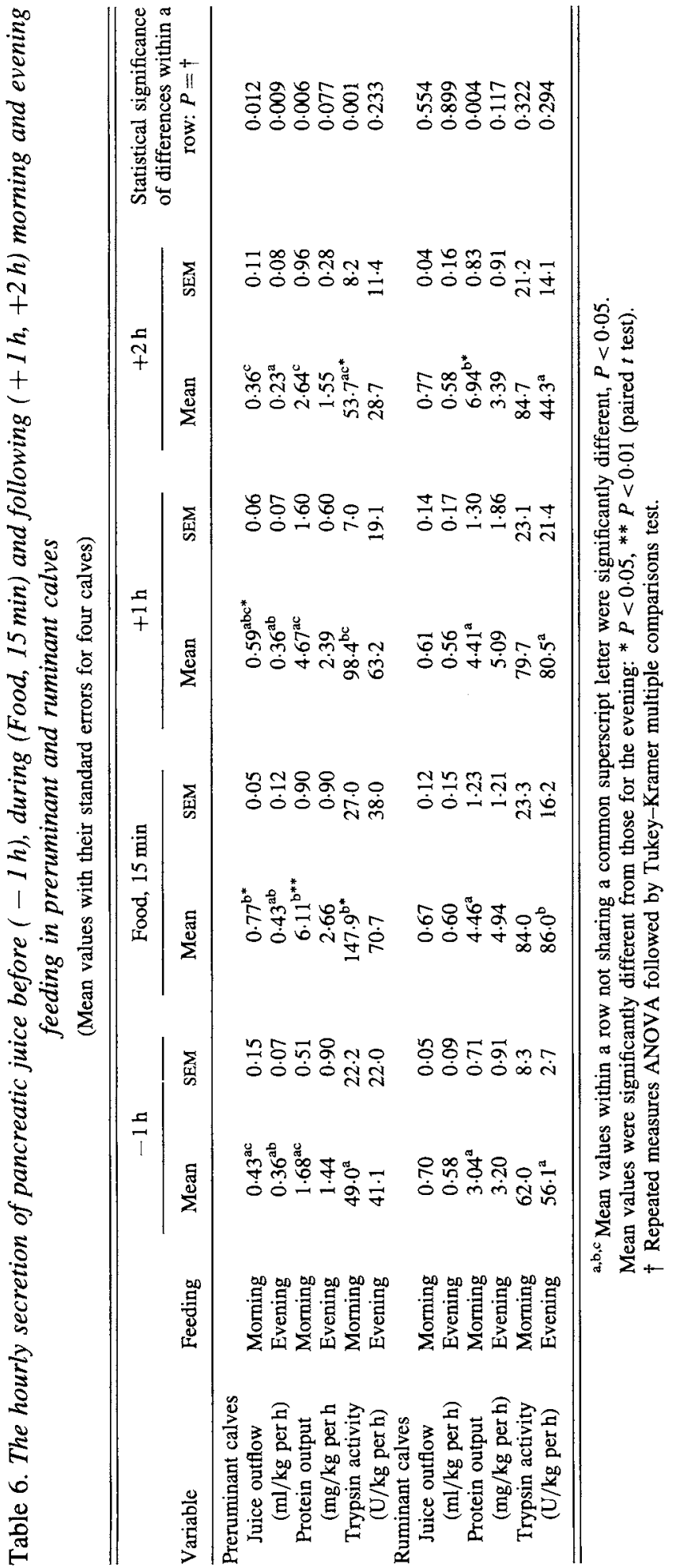


ruminant calves affected the secretion only within the range of preprandial periodic oscillations.

In preruminant calves, the pancreatic secretion during the PPS cycle in which food was administered was significantly elevated as compared with preprandial cycles. This was observed only during morning feeding as shown in Figs. 1, 2 and 3. In the following PPS cycles ( 2 nd to 7 th and 8 th to 13 th), there were no significant differences in the secretion compared with preprandial cycles. Evening feeding did not affect any of the variables measured in preruminant calves and the secretion in the following postprandial cycles did not differ from the preprandial ones. In ruminant calves, no statistically significant differences were found. Except for a tendency towards an increase in the protein and trypsin outputs in the first PPS cycle following food, the PPS cycles following feeding did not differ from the preprandial oscillations.

\section{DISCUSSION}

In the present study, the duodenal electrical activity and exocrine pancreatic secretion were continuously monitored for $24 \mathrm{~h}$ in two groups of calves fed on liquid or solid food. There were no significant differences between morning and evening duodenal MMC and PPS cycles in preruminant calves and a longer duration of evening cycles was observed in ruminant calves. Pancreatic immediate response to food (cephalic phase) was the greatest in preruminant calves following morning feeding. In both preruminant and ruminant calves, food influenced only the PPS cycle in which it was offered. The following postprandial PPS cycles did not differ significantly from the preprandial pancreatic cycles.

\section{Preprandial and postprandial pancreatic secretion}

In the calves studied, there was a marked difference in pancreatic secretion between preruminant and ruminant calves, as has been reported elsewhere (McCormick \& Stewart, 1966; Le Huërou-Luron et al. 1994, 1995; Zabielski, 1994). The amount of secreted pancreatic juice per phase of the PPS cycle and per day was greater in ruminant calves, and the frequency and amplitude of cycles were lower in this group. In contrast, our previous study showed that prolonged maintenance on a liquid diet poorly affects the range of pancreatic juice secretion and the frequency of pancreatic cycles (Zabielski et al. 1994). It seems, therefore, that the type of diet (liquid or solid) is more important in the development of pancreatic exocrine function than the calf's age. In preruminant calves, the mean preprandial secretion was lower and the amplitude of periodic oscillations was greater than in ruminant calves, which may be explained by a different pattern of digesta flow through the duodenum (Girard \& Sissons, 1992). The volume of digesta flowing through the duodenum and its composition differs between preruminant and ruminant calves. Solid food provides more stimulating agents for the pancreas than milk or milk replacer (Kato et al. 1991), whereas milk and skimmed-milk-based milk replacers contain factors that may inhibit pancreatic secretion (e.g. somatostatin; Werner et al. 1985) and delay gastric emptying and small-intestinal transit (e.g. epidermal growth factor; Shinohara et al. 1996). It was also found that the concentrations of plasma cholecystokinin (CCK) and secretin, known to be potent stimulators of pancreatic juice secretion, were higher in ruminant than preruminant calves (Toullec et al. 1992). Besides, CCK and secretin membrane receptors located on pancreatic cells underwent certain development in calves (Le Meuth et al. 1991, 1993). Moreover, CCK stimulates growth of the pancreas in all species examined so far 
(Nylander et al. 1992; Liddle, 1994). These findings taken together may explain higher preprandial pancreatic secretion in ruminant calves in comparison with preruminant calves.

Postprandially, apart from the fluctuations coinciding with the duodenal MMC, we did not observe any obvious elevation in pancreatic juice secretion which could be referred to the second postprandial peak reported by others (McCormick \& Stewart, 1966; Ternouth \& Buttle, 1973). Our results also apparently contrast with the results of Le Huërou-Luron et al. (1994) in the context of juice flow in preruminant calves, since they observed a significant decrease in juice flow simultaneous with an increase in protein concentration in the postprandial period. However, it was not mentioned in their experimental protocol which feeding (morning or evening) was taken into account, whilst in the present study it has been clearly shown that morning and evening feedings produced different pancreatic responses; we also observed a decreasing tendency in juice secretion in the second hour following evening food (see Table 6). Any difference in milk replacer formula, daily amount of food ingested or the mode of feeding could possibly be responsible for these discrepancies between the studies. The comparison of our previous results (Zabielski et al. 1993) obtained following feeding with milk replacer based on soyabean and fish protein with the results obtained following feeding with milk replacer based on skimmed milk and whey in the present study favours this explanation. This comparison revealed markedly lower pancreatic response for the latter formula. Besides, our results obtained in ruminant calves corroborate the daily kinetics of pancreatic juice secretion in ruminant calves reported by Le Huërou-Luron et al. (1995).

In all experimental calves, pancreatic secretion fluctuated in concert with the duodenal MMC before as well as after feeding. A similar observation was reported by Kiela (1996) in weaned pigs fed twice daily. The results obtained in preruminant and ruminant calves and pigs are in contrast with pancreatic profiles obtained in dogs. In the dog, the PPS cycles were observed only when the upper gastrointestinal tract was empty, and each cycle was manifested as a long asecretory period (lasting approximately $1.5 \mathrm{~h}$ ) followed by a shorter secretory period (approximately $30 \mathrm{~min}$ ) (Magee \& Naruse, 1983). Feeding immediately disrupted the MMC and PPS cycles in dogs, replacing them with vigorous electrical and motor activity in the duodenum concomitant with an elevated flow of pancreatic juice rich in enzymes lasting for 5-6 h (Konturek et al. 1986). Another peak of juice secretion rich in bicarbonate was observed 10-11 h after feeding in dogs (Itoh et al. 1980).

\section{Pancreatic response to food ingestion}

The cephalic phase was manifested in preruminant calves as a transient $15 \mathrm{~min}$ increase in pancreatic secretion during and just after food ingestion. A similar pattern was observed in pigs and dogs (Konturek et al. 1986; Kiela, 1996). It has previously been shown that vagal and cholinergic pathways are the most important for stimulation of pancreatic secretion during feeding in calves (Pierzynowski et al. 1992), and that vagi play a permissive role in the action of secretin and CCK in this species (Zabielski et al. 1992b). The difference between morning and evening pancreatic responses to food in preruminant calves could be explained by a greater vagal input to the viscera in the morning. However, the mechanism needs to be clarified. Interestingly, Gullo et al. (1987) reported that pancreatic protein output during breakfast in human subjects was higher than that observed during lunch or dinner. They considered their findings to represent a washout phenomenon after a period of low secretion throughout the night.

Another important observation is the lack of the cephalic phase and a minimal disturbance of the first PPS cycle following feeding in ruminant calves as compared with 
preruminant calves. One possible explanation is the difference in the pattern of the digesta flow in the duodenum (Girard \& Sissons, 1992). That is, in preruminant calves the digesta flow is concentrated within the first few postprandial hours and slow thereafter, whereas in ruminant calves, the digesta flow is more continuous and does not show great variation between the preprandial and postprandial periods. In the latter pattern, the delivery of nutrients into the duodenum can permanently stimulate the exocrine pancreas to a certain level close to maximal stimulation, and therefore the cephalic stimulation via vagal nerves cannot be manifested. The experiment performed on adult sheep (Kato et al. 1984) is in accordance with this hypothesis. Indeed, it was found in this study that pancreatic juice was much more stimulated by food ingestion in sheep in which the flow of digesta into the duodenum was prevented for several hours, than in sheep with undisturbed digesta flow. The neural regulation of the pancreas could also dominate in neonates and the regulatory mechanisms, along with the development of the gastrointestinal tract, may become more and more dependent on gastrointestinal regulatory peptides (e.g. CCK, secretin). Therefore pancreatic response following feeding in neonates may be recognized as an effect of cephalic stimulation via vagi, and minimally related to food ingestion. This supposition can be illustrated by an experiment in which similar pancreatic responses (juice flow and bicarbonate, protein and trypsin outputs) in preruminants were obtained both during feeding with milk replacer and by giving the empty bucket to the calves (V. Leśniewska, P. Kiela and R. Zabielski, unpublished results).

\section{Duodenal and pancreatic biological rhythms}

No relations between abomasal motor activity and sleep were observed in adult ruminants (Ruckebusch, 1975). This was in contrast to marked modifications of the gastrointestinal MMC by sleep in human subjects manifested mainly by a marked reduction in the duration of the ISA phase at night (Kumar et al. 1989; Kellow et al. 1992). Preruminant calves exhibited similar proportions of sleep and wakefulness as adults of non-ruminant species (Ruckebusch, 1975). Therefore, we expected the presence of a circadian pattern of duodenal and pancreatic activities in preruminant calves. In the present study, we did not observe apparent differences between day-time and night-time duodenal MMC and PPS cycles in either preruminant or ruminant calves (except the differences in the initiation of the cephalic phase). In this matter, our study corresponds with a pancreatic secretion study in weaned piglets (Thaela et al. 1995). However, our observations are in contrast with those obtained in adult man with pancreatic duct drainage (Gullo et al. 1987) and in rats with chronically catheterized pancreatic ducts (Maouyo et al. 1993). In the human study there was a noticeable decrease in juice volume and bicarbonate secretion but not in protein output at night. In contrast to the human situation, pancreatic secretion in rats increased in the dark period and decreased in the light period. Our results suggest that the MMC and PPS cycles in calves are little affected by the time of day, which remains in contrast with the results obtained in diurnal (human) and nocturnal (rat) species.

In conclusion, recording of pancreatic cycles along with the duodenal motility enabled us to show the differences between the patterns of pancreatic secretion in preruminant and ruminant calves. These differences were most probably dependent on the anatomical and functional development of the upper gastrointestinal tract which were induced by the change of the diet from liquid to solid.

This work was supported by the State Committee for Scientific Research, grant no. 5 S310 01807. 


\section{REFERENCES}

Abello, J., Laplace, J. P. \& Corring, T. (1988). Biliary and pancreatic secretory component of the migrating myoelectric complex in the pig. Effect on intraduodenal pH. Reproduction, Nutrition, Développement 28, 953-967.

Boldyreff, W. (1911). Einige neue Seiten der Tatigeit des Pancreas (Some new features of pancreatic function). Ergebnisse der Physiologie 11, 121-217.

Erlanger, B. F., Kokowsky, N. \& Cohen, W. (1961). The preparation and properties of two new chromogenic substrates of trypsin. Archives of Biochemistry and Biophysics 95, 271-278.

Girard, C. L. \& Sissons, J. W. (1992). The role of migrating myoelectric complexes in the regulation of digesta transport in the preruminant calf. Canadian Journal of Physiology and Pharmacology 70, 1142-1147.

Guilloteau, P., Corring, T., Garnot, P., Martin, P., Toullec, R. \& Durand, G. (1983). Effects of age and weaning on enzyme activity of abomasum and pancreas of the lamb. Journal of Dairy Science 66, 2373-2385.

Guilloteau, P., Le Huërou-Luron, I., Chayvialle, J. A., Moutas, A., Bernard, C., Cuber, J. C., Burton, J., Puigserver, A. \& Toullec, R. (1992). Plasma and tissue levels of digestive regulatory peptides during postnatal development and weaning in the calf. Reproduction, Nutrition, Développement 32, 285-296.

Gullo, L., Pezzilli, R., Priori, P., Baldoni, F., Paparo, F. \& Mattioli, G. (1987). Pure pancreatic juice collection over 24 consecutive hours. Pancreas 2, 620-623.

Itoh, Z., Honda, R. \& Hiwatashi, K. (1980). Biphasic secretory response of exocrine pancreas to feeding. American Journal of Physiology 238, G332-G337.

Kato, S., Katoh, K. \& Barej, W. (1991). Regulation of exocrine pancreatic secretion in ruminants. In Physiological Aspects of Digestion and Metabolism in Ruminants, pp. 89-109 [T. Tsuda, Y. Sasaki and R. Kawashima, editors]. San Diego, CA: Academic Press Inc.

Kato, S., Usami, M. \& Ushijima, J. (1984). The effect of feeding on pancreatic exocrine secretion in sheep. Japanese Journal of Zootechnical Science 55, 973-977.

Kellow, J. E., Eckersley, G. M. \& Jones, M. (1992). Enteric and central contributions to intestinal dysmotility in irritable bowel syndrome. Digestive Diseases and Sciences 37, 168-174.

Kiela, P. (1996). Integrative role of some intestinal bioactive peptides in the regulation of pancreatic exocrine secretion and the MMC of the stomach and small intestine in piglets. PhD Thesis in Veterinary Medicine, Warsaw Agricultural University.

Kiela, P., Zabielski, R., Podgurniak, P., Midura, M., Barej, W., Gregory, P. C. \& Pierzynowski, S. G. (1996). Cholecystokinin-8 and Vasoactive Intestinal Polypeptide stimulate exocrine pancreatic secretion via duodenal mediated mechanisms in the conscious pig. Experimental Physiology 81, 375-384.

Konturek, S. J., Thor, P. J., Bilski, J., Bielański, W. \& Laskiewicz, J. (1986). Relationships between duodenal motility and pancreatic secretion in fasted and fed dogs. American Journal of Physiology 250, G570-G574.

Kumar, D., Soffer, E. E., Wingate, D. L., Britto, J., Das-Gupta, A. \& Mridha, K. (1989). Modulation of the duration of human postprandial motor activity by sleep. American Journal of Physiology 256, G851-G855.

Le Huërou, I., Wicker, C., Guilloteau, P., Toullec, R. \& Puigserver, A. (1990). Specific regulation of the gene expression of some pancreatic enzymes during postnatal development and weaning in the calf. Biochimica et Biophysica Acta 1048, 257-264.

Le Huërou-Luron, I., Le Drean, G., Chayvialle, J. A., Bernard, C., Rome, V., Toullec, R. \& Guilloteau, P. (1994). Are secretin and cholecystokinin (CCK) involved in the regulation of postprandial pancreatic juice secretion in preruminant calves? Preliminary results concerning juice flow and protein concentration and plasma regulatory peptides levels. Proceedings of the Society of Nutrition Physiology 3, 298.

Le Huërou-Luron, I., Le Drean, G., Chayvialle, J. A., Rome, V., Bernard, C., Toullec, R. \& Guilloteau, P. (1995). Daily pancreatic secretion and its relation with CCK, gastrin and secretin plasmatic levels in ruminant calves. Preliminary results. Annales de Zootechnie 44, Suppl., 282.

Le Meuth, V., Farjaudon, N., Bawab, W., Chastre, E., Rosselin, G., Guilloteau, P. \& Gespach, C. (1991). Characterization of binding sites for VIP-related peptides and activation of adenylate cyclase in developing pancreas. American Journal of Physiology 260, G265-G274.

Le Meuth, V., Philouze-Rome, V., Le Huërou-Luron, I., Formal, M., Vaysse, N., Gespach, C., Guilloteau, P. \& Fourmy, D. (1993) Differential expression of A- and B-subtypes of cholecystokinin/gastrin receptors in the developing calf pancreas. Endocrinology 133, 1182-1191.

Liddle, R. A. (1994). Cholecystokinin. In Gut Peptides: Biochemistry and Physiology. [J. H. Walsh and G. J. Dockray, editors]. New York: Raven Press.

Lowry, O. H., Rosebrough, N. J., Farr, A. L. \& Randall, R. J. (1951). Protein measurement with the Folin phenol reagent. Journal of Biological Chemistry 193, 165-175.

Magee, D. F. \& Naruse, S. (1983). Neural control of periodic secretion of the pancreas and the stomach in fasting dogs. Journal of Physiology 344, 153-160.

Maouyo, D., Sarfati, P., Guan, D., Morisset, J. \& Adelson, J. W. (1993). Circadian rhythm of exocrine pancreatic secretion in rats: major and minor cycles. American Journal of Physiology 264, G792-G800.

McCormick, R. J. \& Stewart, W. E. (1966). Pancreatic secretion in the bovine calf. Joumal of Dairy Science 50, 568-571. 
Naranjo, J. A., Valverde, A., Martínez de Victoria, E., Mañas, M. \& Moreno, J. (1986). Surgical preparation for the study of pancreatic exocrine secretion in the conscious preruminant goat. Laboratory Animals 20, 231233.

Nylander, A.-G., Chen, D., Ihse, I., Rehfeld, J. F. \& Hakanson, R. (1992). Pancreatic atrophy in rats produced by the cholecystokinin-A receptor antagonist devazepide. Scandinavian Journal of Gastroenterology 27, 743747.

Onaga, T., Zabielski, R., Mineo, H. \& Kato, S. (1993). The temporal coordination of interdigestive pancreatic exocrine secretion and intestinal migrating myoelectric complex in rats. In Proceedings of XXXII Congress of the International Union of Physiological Sciences, Glasgow, 95.1/P., p. 83. Glasgow: Internationl Union of Physiological Sciences Publications.

Pierzynowski, S. G., Weström, B. R., Svendsen, J. \& Karlsson, B. W. (1990). Development of exocrine pancreas function in chronically cannulated pigs during 1-13 weeks of postnatal life. Journal of Pediatric Gastroenterology and Nutrition 10, 206-212.

Pierzynowski, S. G., Zabielski, R., Podgurniak, P., Kiela, P., Sharma, P., Weström, B. R., Kato, S. \& Barej, W. (1992). Effects of reversible cold vagal blockade and atropinization on exocrine pancreas function during liquid food consumption in calves. Journal of Animal Physiology and Animal Nutrition 67, 268-273.

Pierzynowski, S. G., Zabielski, R., Weström, B., Mikolajczyk, M. \& Barej, W. (1991). Development of the exocrine pancreatic function in chronically cannulated calves from the preweaning period up to early rumination. Journal of Animal Physiology and Animal Nutrition 65, 165-172.

Podgurniak, P. \& Pierzynowski, S. G. (1993). Relation between the electrical activity of the duodenum and pancreatic juice secretion in calves. Chinese Medical Science Journal 8, Suppl., 75.

Ruckebusch, Y. (1975). Motility of the ruminant stomach associated with states of sleep. In Digestion and Metabolism in the Ruminant, pp. 77-90 [W. McDonald and A. C. I. Warner, editors]. Armidale, Australia: The University of New England Publishing Unit.

Ruckebusch, Y. \& Bueno, L. (1973). The effect of weaning on the motility of the small intestine in the calf. British Journal of Nutrition 30, 491-499.

Ruckebusch, Y., Dardillat, C. \& Guilloteau, P. (1983). Development of digestive functions in the newborn ruminant. Annales de Recherches Veterinaires 14, 360-374.

Shinohara, H., Williams, C., Yakabe, T. \& Koldovsky, O. (1996). Epidermal growth factor delays gastric emptying and small intestinal transit in suckling rats. Pediatric Research 39, 281-286.

Ternouth, J. H. \& Buttle, H. L. (1973). Concurrent studies of the flow of digesta in the duodenum and of exocrine pancreatic secretion of calves. The collection of the exocrine pancreatic secretion from a duodenal cannula. British Journal of Nutrition 29, 387-397.

Ternouth, J. H., Roy, J. H. B. \& Shotton, S. M. (1976). Concurrent studies of the flow of digesta in the duodenum and of exocrine pancreatic secretion of calves. The effect of age. British Jourmal of Nutrition 36, 523-535.

Thaela, M. J., Pierzynowski, S. G., Jensen, M. S., Jackobsen, K., Weström, B. R. \& Karlsson, B. W. (1995). The pattern of the circadian rhythm of pancreatic secretion in fed pigs. Journal of Animal Science 73, 3402-3408.

Toullec, R., Chayvialle, J. A., Guilloteau, P. \& Bernard, C. (1992). Early-life patterns of plasma gut regulatory peptide levels in calves. Effect of age, weaning and feeding. Comparative Biochemistry and Physiology 102A, 203-209.

Vantrappen, G. R., Peeters, T. L. \& Janssens, J. (1979). The secretory component of the interdigestive migrating motor complex in man. Scandinavian Journal of Gastroenterology 14, 663-667.

Werner, H. T., Amarant, R. P., Millar, M., Fridkin, M. \& Koch, Y. (1985). Immunoreactive and biologically active somatostatin in human and sheep milk. European Journal of Biochemistry 148, 353-357.

Zabielski, R. (1994). Function of exocrine pancreas in growing calves. In The Developing of Digestive and Metabolic Processes in New Born and Growing Ruminants, Proceedings of Satellite Symposium to VIII ISRP, pp. 21-28 [W. Barej, R. Zabielski and P. Ostaszewski, editors]. Warsaw, Poland: Fundacja "'Rozwój SGGW'.

Zabielski, R., Kato, S., Pierzynowski, S. G., Mineo, H., Podgurniak, P. \& Barej, W. (1992a). Effects of intraduodenal $\mathrm{HCl}$ and soybean extract on pancreatic juice secretion during atropinization and cold vagal blockade in calves. Experimental Physiology 77, 807-817.

Zabielski, R., Onaga, T., Mineo, H. \& Kato, S. (1993). Periodic fluctuations in pancreatic secretion and duodenal motility investigated in neonatal calves. Experimental Physiology 78, 675-684.

Zabielski, R., Pierzynowski, S. G., Podgurniak, P. \& Barej, W. (1992b). Effect of secretin and cholecystokinin octapeptide (CCK8) on exocrine pancreas during cold vagal blockade in calves. Journal of Animal Physiology and Animal Nutrition 67, 173-180.

Zabielski, R., Terui, Y., Onaga, T., Mineo, H. \& Kato, S. (1994). Plasma secretin fluctuates in phase with pancreatic periodic secretion and duodenal migrating myoelectric complex in calves. Research in Veterinary Science 56, 332-337. 